\title{
Household Debt and the Great Recession
}

\author{
Carlos Garriga, Bryan Noeth, and Don E. Schlagenhauf
}

In the mid-2000s, household private debt reached a new level 1.2 times larger than personal incomebefore collapsing during the Great Recession. This paper uses microeconomic data to document the main changes in personal debt and explore the behavior of debt across generations over two periods: before and after the Great Recession. Special emphasis is placed on participation rates by category of debt (the extensive margin), volume borrowed (the intensive margin), and default behavior. Key findings include that between 1999 and 2013 the fraction of individuals with only unsecured (e.g., credit card) debt decreased, as did their balances. In addition, most forms of private debt (mortgages, credit card debt, and auto loans) had significant boom-bust cycles, but the effects across generations have been very asymmetric. (JEL D14, D31)

Federal Reserve Bank of St. Louis Review, Second Quarter 2017, 99(2), pp. 183-205.

https://doi.org/10.20955/r.2017.183-205

\section{INTRODUCTION}

Since World War II, U.S. households have been taking on larger levels of debt, which played an important role during the Great Recession. Figure 1 shows the ratio of household debt to personal income (hereafter the debt-to-income ratio) and the ratio of household debt to disposable income (net of taxes and transfers) from 1952 to 2015. 1 In the early post-World War II years, credit was not widely used and the debt-to-income ratio was around 31 percent, but it increased to 81 percent in 2000. During the housing boom of the early 2000s, the debtto-income ratio increased significantly, growing approximately 50 percentage points between 1990 and 2008.

At the peak of the boom, household debt-which includes mortgages, automobile loans, unsecured debt (e.g., credit cards), and student loans - was around 1.2 times larger than personal income (or slightly higher if one considers disposable income). The Great Recession curtailed the growth of credit and household debt. As a result, household debt has declined

Carlos Garriga is an assistant vice president and economist, Bryan Noeth is a senior specialist, and Don E. Schlagenhauf is an economist at the Federal Reserve Bank of St. Louis. The authors are grateful for stimulating discussions with YiLi Chien, Juan M. Sanchez, Eric Young, David Wiczer, Stephen Williamson, and Yi Wen.

(c) 2017, Federal Reserve Bank of St. Louis. The views expressed in this article are those of the author(s) and do not necessarily reflect the views of the Federal Reserve System, the Board of Governors, or the regional Federal Reserve Banks. Articles may be reprinted, reproduced, published, distributed, displayed, and transmitted in their entirety if copyright notice, author name(s), and full citation are included. Abstracts, synopses, and other derivative works may be made only with prior written permission of the Federal Reserve Bank of St. Louis. 
Figure 1

Debt-to-Income Ratios

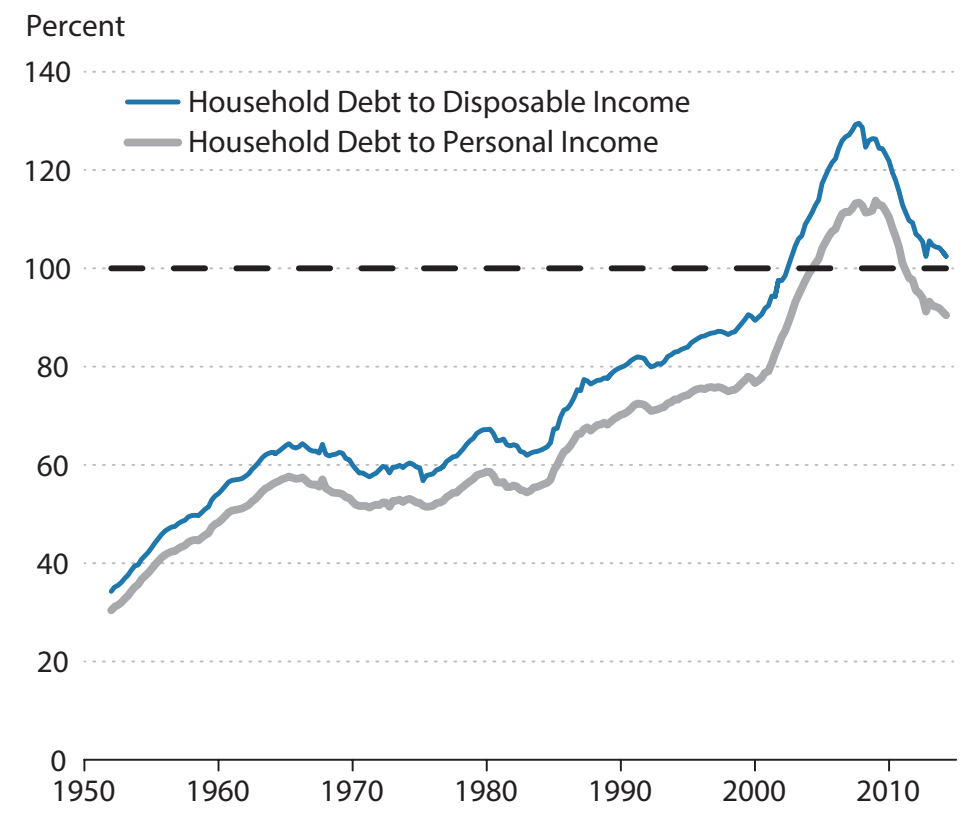

SOURCE: Board of Governors of the Federal Reserve System and Bureau of Economic Analysis.

since 2008 and once again fell below 100 percent after 2010. The decrease in household debt has often been referred to as household deleveraging and has been viewed as a key factor in the sluggish recovery from the 2007-09 financial crises. As a result, policymakers have been concerned about the possible harmful effects of excess private borrowing and possible consequent deleveraging.

An obvious question is whether policymakers should be concerned about private debt. In 1933, Irving Fisher offered a theory of business cycles that states private over-indebtedness plays a key role in generating severe recessions and even depressions. Fisher argued that if households take on too much debt, they may decide to rebalance their balance sheets through bankruptcy and distressed sales. A massive selloff can lead to a decline in prices. As a result, firms' net worth may fall, resulting in additional bankruptcies and declining output. A decrease in employment may follow, resulting in additional bankruptcies and another contractionary round for the economy. Fisher had the Great Depression in mind, which started in 1929. If one thinks about the boom in the housing market in the 2000s and the resulting amount of mortgage debt, however, the collapse of the housing market and the resulting severe recession-the Great Recession—seems to be consistent with Fisher's theory.

This paper examines the role debt played in the Great Recession, exploring which forms of household debt contributed to the large increase in aggregate debt during the pre-recession economic expansion (boom) and subsequent collapse (bust). We use a very simple macro- 
economic framework - the life-cycle model, which allows an individual or household to have a mismatch of income and consumption expenditures over a lifetime. Early in life, income tends to be low, yet consumption demands can be high. This mismatch is likely to result in borrowing. As individuals age, earnings tend to increase and consumption expenditures may increase also, but usually at a slower rate. The result is a natural opportunity to pay off debts incurred when young and start saving. This trend continues until retirement, when income falls and consumption continues. This mismatch results in drawing down savings.

This framework stresses that household debt, when considered over a lifetime, is not necessarily a warning signal. For example, mortgage debt allows newly formed households to purchase homes and student loans allow individuals to get a college education. Ignoring lifecycle aspects could result in a biased evaluation of the use of credit. $\underline{2}$ The key issue, or tipping point, is at what level does borrowing expose individuals to the excessive risk discussed by Fisher.

Empirical evidence provides a clear picture of how earnings, income, and net worth vary over an individual's lifetime as well as how the patterns of such changed before and after the Great Recession, including borrowing patterns for mortgage, auto, and student loans. Understanding these patterns provides guidance on the role that debt accumulation and deleveraging played during the Great Recession.

We analyze micro-level data for the period 1999-2013 by age cohort, which reveals several important key findings. The distributions of unsecured (credit card) debt are hump-shaped, with the peaks occurring for the cohorts between ages 41-55. Conditional on a particular age cohort, the distribution of debt balances is skewed. Between 1999 and 2013, the fraction of individuals/households with only unsecured debt decreased, as did the size of their balances.

There is a nontrivial number of individuals in the sample with credit card balances and mortgage debt. Relative to the number of individuals that hold only unsecured debt, these individuals have much larger average balances. This finding is not surprising given the amount needed to finance a home. Unlike auto and student debt, unsecured and mortgage debt increased dramatically between 1999 and 2008. However, the Great Recession and its aftermath brought these debt levels substantially below 1999 levels, particularly for individuals under age 40 .

The Great Recession led to a period of deleveraging for all individuals that resulted in a reduction of their unsecured balances significantly.

\section{UNDERSTANDING HOUSEHOLD BORROWING DECISIONS: THE LIFE-CYCLE FRAMEWORK}

The life-cycle model can be used to understand a household's borrowing decisions. ${ }^{3}$ This framework studies how a household (or individual) makes consumption decisions over a lifetime as income varies. Understanding the mismatch between consumption and income is essential for understanding household borrowing (saving) for predictable and smooth consumption to obtain the desired consumption plan. 


\section{Garriga, Noeth, Schlagenhauf}

Consider an individual or household with a life span denoted by a finite number of periods, $T$. Different paths of consumption over the life cycle are evaluated using a utility index, $u(c)$, that satisfies $u^{\prime}>0$ and $u^{\prime \prime}<0$. The individual has an internal discount rate represented by $\beta>0$ and disposable income, $y_{t}$, that changes over the life cycle, $t$. Income can be transferred over time by borrowing or lending, $a$, at a cost (the interest rate) $r \geq 0$. The consumer solves the problem

$$
\begin{aligned}
\max _{\left\{c_{t}, a_{t+1}\right\}_{t=1}^{T}} \sum_{t=1}^{T} \beta^{t-1} u\left(c_{t}\right) \\
\text { s.t. } \quad c_{t}+a_{t+1}=y_{t}+a_{t}(1+r), \\
a_{1}=0,
\end{aligned}
$$

where for simplicity, the initial endowment of non-labor income is $0, a_{1}=0$. In this formulation, the individual does not leave any resources beyond period $T$, hence, $a_{T+1}=0$. Simply stated, the individual does not make bequests. Let $\lambda_{t}$ be the Lagrange multiplier of the budget constraint in period $t$. The first-order conditions with respect to $c_{t}$ and $a_{t+1}$ are given by

$$
\begin{aligned}
& \beta^{t-1} u^{\prime}\left(c_{t}\right)=\lambda_{t}, \\
& \lambda_{t}=\lambda_{t+1}(1+r) .
\end{aligned}
$$

Combining both expressions results in the equation that determines the intertemporal tradeoff between consumption today and consumption tomorrow:

$$
\frac{u^{\prime}\left(c_{t}\right)}{u^{\prime}\left(c_{t+1}\right)}=\beta(1+r) .
$$

This equation is commonly known as the Euler equation. The left-hand side of the equation represents the growth rate of consumption over the life cycle. The right-hand side determines that the growth rate of consumption has to be equal to $\beta(1+r)$. If the term is larger (smaller) than 1, then consumption grows (decreases) as the individual ages. For simplicity and without loss of generality, assume that $\beta(1+r)=1$. In this case, the individual will choose constant consumption over the life cycle, $c^{*}$ :

$$
u^{\prime}\left(c_{t}\right)=u^{\prime}\left(c_{t+1}\right) \Rightarrow c_{t}=c_{t+1}=c^{*} .
$$

In the basic life-cycle model, savings are used to achieve the desired consumption path. Hence, consumption is not determined in a particular period by the amount of labor income earned in that period. Rather, consumption in that period depends on life-time earnings, or permanent income, $Y$. The value for permanent income can be found by combining all the budget constraints for each period of life into one equation, or

$$
\sum_{t=1}^{T} \frac{c_{t}}{(1+r)^{t-1}}=Y=\sum_{t=1}^{T} \frac{y_{t}}{(1+r)^{t-1}}
$$

Solving the consumer's optimization problem yields the same Euler equation. Under the assumptions that $\beta(1+r)=1$, one can easily characterize the optimal level of consumption, $c^{*}$, as 


$$
c^{*}=\frac{Y}{\sum_{t=1}^{T} \frac{1}{(1+r)^{t-1}}} .
$$

If the path of income coincides with the path of consumption, that is

$$
c^{*}=y_{t} \frac{\sum_{t=1}^{T} \frac{1}{(1+r)^{t-1}}}{\sum_{t=1}^{T} \frac{1}{(1+r)^{t-1}}}=y^{*},
$$

then the individual does not need to borrow or save over the life cycle. In general, the laborincome path does not coincide with the consumption path and as a result the individual borrows/saves. Younger individuals who enter the labor market usually earn less income. Yet, they may desire to purchase an auto or a house along with some durable goods. Obviously, these individuals must borrow in the early years, $c^{*}>y_{t}$, and delay saving until later in the life cycle, $c^{*}<y_{t}$. The path of borrowing/saving follows

$$
\begin{aligned}
a_{2}= & y_{1}-c^{*}, \\
a_{3}= & y_{2}+a_{2}(1+r)-c^{*}, \\
& \ldots \\
a_{t+1}= & y_{t}+a_{t}(1+r)-c^{*}, \\
& \ldots \\
a_{T}= & y_{T-1}+a_{T-1}(1+r)-c^{*},
\end{aligned}
$$

and in the last period satisfies

$$
c^{*}=y_{T}+a_{T}(1+r)
$$

The life-cycle model is depicted in Figure 2. Following the empirical evidence presented in Section 3, the figure presents an individual's earnings (income) as a humped-shaped pattern. Early entrants into the labor market earn lower wages and thus have lower earnings. As an individual builds human capital and gains experience in the labor market, earnings increase. The data suggest that earnings continue to increase until about the mid-50s. During the remaining working life, individual earnings tend to remain flat or decline slightly. At retirement, labor earnings drop to zero. Ideal consumption spending is drawn as a horizontal line, indicating the individual would like to consume the same amount of goods each period of their life: $c_{t}=c_{t+1}=c^{*}$.

The mismatch between income and expenditures is clearly depicted in Figure 2. When an individual is young (with age closer to the vertical axis), desired consumption exceeds earnings or income, so desired consumption is achieved by borrowing (negative saving). For example, a young individual may want to invest in higher education to acquire human capital to earn more in the future. This investment can occur only with a student loan. Life-cycle factors can also motivate borrowing. For example, a young individual might want to purchase a "big ticket" item such a house or a car. The individual could delay the purchase until having 
Figure 2

Why Do Households Borrow (or Save)?: Consumption and Income Over the Life Cycle

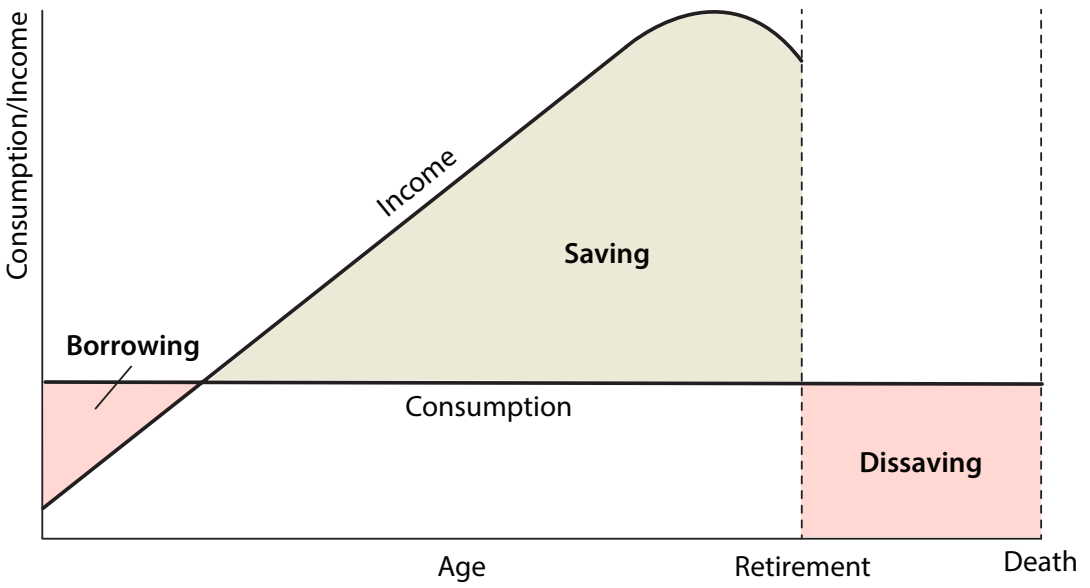

saved or, alternatively, could borrow and benefit from the purchase immediately. Later in life, the individual may be retired and earn no income. As shown in Figure 2, a constant level of consumption can be maintained in retirement only if the individual has sufficient savings to finance expenditures. The buffer of savings must be developed in mid-life, when income exceeds consumption.

The message from the life-cycle framework is clear. Over an individual's life, there is a natural mismatch between income and consumption. As a result, the individual borrows. This mismatch also tells us that debt on an individual's balance sheet does not necessarily indicate a financial problem. A financial problem occurs only if debts cannot be paid off over the individual's lifetime. $\underline{4}$

It is important to emphasize other important reasons to use credit over the life cycle not captured by the model. For example, individuals can be exposed to negative income shocks (e.g., for healthcare or repairs of durable goods such as homes and automobiles) or purchase "lumpy" investment goods (e.g., housing or human capital investment through a college education). It is relatively straightforward to expand the basic life-cycle model to include negative income shocks and lumpy investments. An expanded version of this model that includes additional margins is discussed by Chambers, Garriga, and Schlagenhauf (2009).

\section{WHAT HAS HAPPENED TO HOUSEHOLD EARNINGS AND NET WORTH SINCE 1990?}

We first examine the impact of the Great Recession on household (or individual) income. Although the terms income and earnings have already been used herein, these terms must be formally defined. Earnings are the reward (payment) for any type of labor activity, which 


\section{Figure 3}

\section{Average Earnings and Net Worth of Families by Age Cohort}

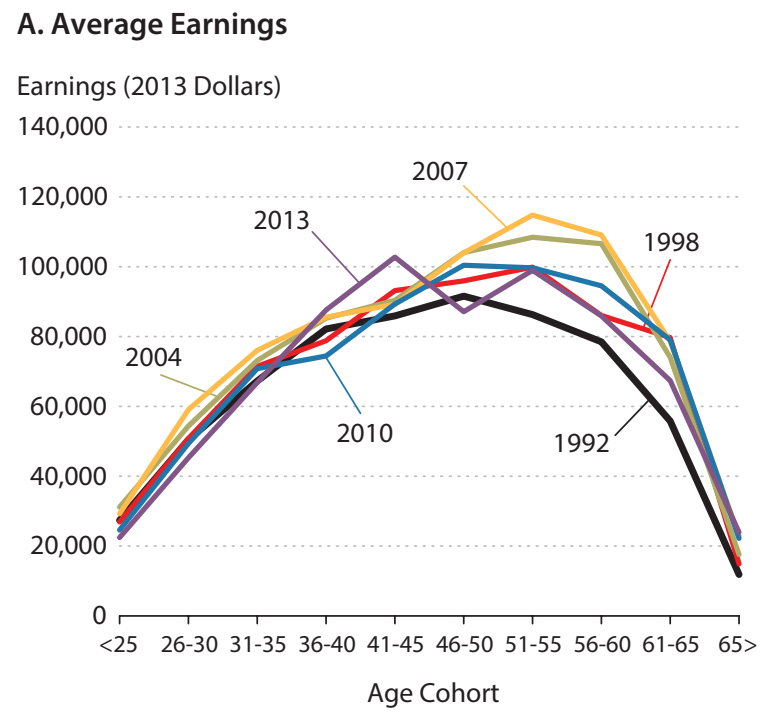

B. Net Worth

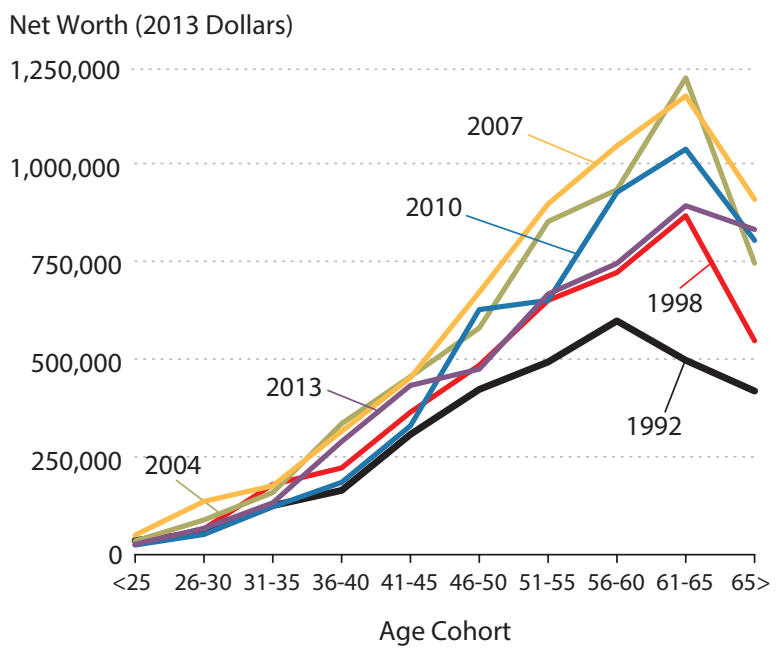

SOURCE: Survey of Consumer Finances and authors' calculations.

includes entrepreneurial labor. Income is a broad measure that includes earnings as well as rental income and capital income such as interest and dividends. In addition, income also includes government transfers. Both income and earnings are often considered flow variables because they are received each month, quarter, or year. Another measure of an individual's well-being is net worth, which differs from earnings and income. Net worth is considered a stock variable because it depends on past decisions and measures the value of all assets net of debt.

This section uses data from the Survey of Consumer Finance to examine the evolution of the average real earnings and real net worth of families for various age cohorts and years over the 1990 to 2013 period, which includes the Great Recession. As Panel A of Figure 3 shows, average earnings (which begin in 1992) exhibited a hump-shaped pattern, with the peak of earnings changing over the past 25 years. $\underline{5}$ Average earnings in 1992 peaked for the 46-50 cohort. Average earnings in 1998 remained essentially the same for cohorts younger than 41 but started increasing for the 41-45 cohort, with the peak shifting to the 51-55 cohort. Average earnings in 2004 and 2007, the years prior to the start of the Great Recession, increased across all cohorts, with cohorts between 46 and 65 showing the largest increases. Relative to the peak years, 2010 shows a large decline for all households. By 2013, the Great Recession had been underway for a few years, and average earnings seem to have declined to near 1998 levels, with gains lost for cohorts between 46 and 65 . One important lesson from these patterns is that changes in earnings do not occur uniformly across all ages-some cohorts seem to have more rapid increases than others. 


\section{Figure 4}

\section{The Great Recession's Impact on Minorities by Age Cohort}
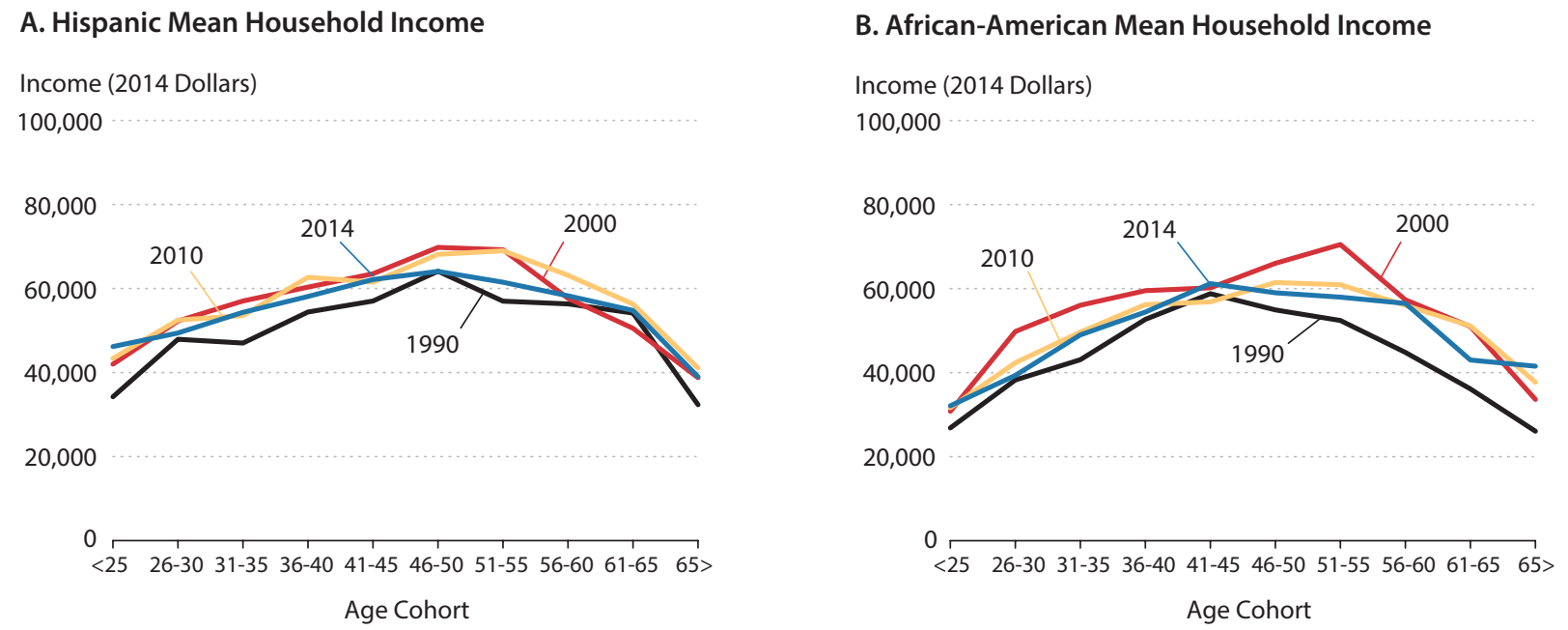

SOURCE: Current Population Survey Annual Social and Economic Supplement and authors' calculations.

Net worth (Panel B of Figure 3) follows a very different pattern from earnings. The lifecycle model suggests that as individuals or households save, their net worth should increase except at the very end of their lifetimes. Wealth remaining after an individual's death indicates the inherent timing problem and/or a desire to leave bequests. The evolution of net worth changed dramatically between 1992 and 2013. For example, net worth in 1992 peaked for the 56-60 cohort, which is at a later age than the peak in income. Net worth in 1998 increased for all cohorts, with the peak moving to the 61-65 cohort. During the years of the 2004-07 housing boom, the peak of net worth substantially increased for the 61-65 cohort. Most of this increase can be attributed to the rapid appreciation of housing prices. Net worth during the years 2010 and 2013 reflects the collapse of the housing market in certain parts of the United States during the Great Recession: Gains in net worth generally halted and rolled back to 1998 levels.

Although the previous estimates captured average behavior, they may not represent the impact of the Great Recession on the earnings of minorities, such as African Americans and Hispanics. While data on minorities are limited in the Survey of Consumer Finances, more information is available from the Current Population Survey Annual Social and Economic Supplement, which is used to expand the sample size. The main disadvantage of this source is that it does not contain information on assets and debt. However, the survey does contain much more detailed income data. Figure 4 shows mean household income (in 2014 dollars) for Hispanics (Panel A) and African-Americans (Panel B).

While the pattern of income for both Hispanics and African Americans is hump-shaped, the levels and peaks vary between the two and across years. For Hispanics (see Panel A of 
Figure 4), mean household income peaked around the ages 46 to 50 in all years but remained substantially below the average income of all households in 1992 (see Panel A of Figure 3, solid black line). For example, in 1992, average income for the all-households 46-50 cohort was over $\$ 80 \mathrm{~K}$, while mean household income for the corresponding Hispanic cohort was about \$60K. 6 Between 1990 and 2010, real income increased for all Hispanic cohorts, but the increase was less than $\$ 10 \mathrm{~K}$ each. The Great Recession caused a loss in real income for most Hispanic cohorts. Although by 2010 income for most Hispanic cohorts moved back to 2000 levels, income for cohorts between ages 46 and 65 moved closer to 1990 levels.

The impact of the Great Recession on African Americans was similar to that on Hispanics (see Panel B of Figure 4). As with Hispanics, mean household income for African Americans in 1990 was substantially below the average income of all households in 1992 (see Panel A of Figure 3, solid black line). In addition, mean income for younger and older African-American cohorts was somewhat lower than for their Hispanic counterparts. Between 1990 and 2000 there is pronounced upward movement in mean income across all African-American cohorts. The Great Recession negated much of these gains.

Figures 3 and 4 clearly show a symmetric distribution of the changes in income and net worth across age cohorts and ethnic groups before and after the Great Recession. Issues of inequality during the Great Recession have attracted the attention of both policymakers and the popular press. Some economists have been arguing that the United States has been facing important trends in inequality during the past 20 years. The goal of this analysis is not to understand such trends but rather to see how changes in income have affected a household's ability to borrow or repay previously acquired debts. A simple and direct way to measure this change is to compare changes in household income relative to the median household using data from the Survey of Consumer Finance. In particular, the analysis compares the average earnings, income, and net worth of households in the 50th percentile (median households) with those in the 30th percentile (low end) and 90th percentile (upper end) of the distribution. These comparisons are often called the 30-50 ratio and 90-50 ratio, respectively. $\underline{7}$

The left-hand side of Table 1 shows the 30-50 ratios. In 1992, average earnings of median households were 3.62 times greater than those of households in the 30th percentile. From 1992 to 2007 , this disparity declined to 2.68 . For income, the $30-50$ ratio is approximately constant, which may seem surprising. The 30-50 income ratio did not vary widely over that time because of government transfer programs, which prop up households in the lower part of the income distribution. Lower-income households, however, have more challenges for accumulating wealth. The 30-50 net-wealth ratio shows a slight increase in disparity, from 3.83 in 1992 to 4.53 in 2007. During the boom period, median households (probably home owners) accumulated wealth more rapidly than households in the 30 th percentile.

The Great Recession ended the decline in the 30-50 earnings ratio. In 2013, average earnings of median households were 3.30 times larger than those of households in the 30th percentile. In other words, the disparity reverted back nearly to the 1992 level of 3.62. A more startling result is discovered for net worth: The Great Recession increased disparity. In 1992, net worth of median households was 3.83 times larger than that of households in the 30th percentile. By 2013, that number increased to 5.49. Two factors help explain this increase: Households 


\section{Table 1}

\section{Income Distribution}

\begin{tabular}{|c|c|c|c|c|c|c|}
\hline \multirow[b]{2}{*}{ Date } & \multicolumn{3}{|c|}{ 30-50 Ratio } & \multicolumn{3}{|c|}{ 90-50 Ratio } \\
\hline & Earnings & Income & Net worth & Earnings & Income & Net worth \\
\hline 1992 & 3.62 & 1.69 & 3.83 & 3.35 & 2.94 & 7.18 \\
\hline 1998 & 2.80 & 1.67 & 4.00 & 3.22 & 2.78 & 6.88 \\
\hline 2004 & 2.68 & 1.69 & 3.98 & 3.50 & 3.00 & 9.02 \\
\hline 2007 & 2.69 & 1.64 & 4.53 & 3.47 & 2.98 & 7.55 \\
\hline 2010 & 3.40 & 1.62 & 5.23 & 3.72 & 3.11 & 12.35 \\
\hline 2013 & 3.30 & 1.64 & 5.49 & 4.07 & 3.31 & 11.58 \\
\hline
\end{tabular}

SOURCE: Survey of Consumer Finances.

in the lower part of the income distribution (i) started with relatively little savings and (ii) are hit harder by recessions. Although median households suffer, it is relatively less than households at the bottom of the income distribution. Between 1992 and 2007, more households owned homes. As house values increased over this time, so did net worth. After 2008, house values declined, yet the 30-50 net-worth ratio increased to 5.49. An important driver of this effect was the asymmetric decline in housing prices. The median house price in most metropolitan areas declined to less than the price of starter homes (the bottom tier in the housing market). This decline would certainly have had a larger impact on homeowners on the bottom of the distribution compared with median homeowners.

The right-hand side of Table 1 shows the 90-50 ratios. In 1992, households in the 90th percentile had earnings 3.35 times larger than those of median households. For income in the same year, the 90-50 ratio was 2.94. For both earnings and income, the 90-50 ratios were relatively constant through 2007. However, starting in 2010, the 90-50 ratios for both earnings and income began to increase. By 2013, average earnings for a household in the 90th percentile were 4.07 times larger than those of median households and average income was 3.31 times larger.

These increases in disparity, however, are small compared with the changes in the 90-50 net-worth ratio. Between 1992 and 2007, average net worth of households in the 90th percentile was approximately 7.55 times larger than that of median households. After 2007, the disparity grew substantially. In 2010, the 90-50 net-worth ratio reached 12.35 and then slightly declined to 11.58 in 2013. A possible explanation for this large increase is the performance of the stock market: The S\&P 500 index increased 11 percent between 1990 and 2013. Research indicates that participation in the stock market increases wealth, with richer households being more likely to hold risky assets than poorer households. In 2013, the richest 10 percent of households owned over 80 percent of total stocks. It is reasonable, therefore, that the recent performance of the stock market is a factor in the increase of the 90-50 net-worth ratio. 


\section{WHAT HAS HAPPENED TO HOUSEHOLD DEBT SINCE 1990?}

As noted earlier, household debt increased substantially from 1990 to 2008 and then rapidly declined. The decline is often referred to as household deleveraging. To understand changes in various forms of household debt, the analysis in this section uses the Federal Reserve Bank of New York Consumer Credit Panel based on data provided by Equifax, a consumer credit reporting agency. The dataset provides a 5 percent random sample of credit reports of five million individuals. The debt holdings of the individuals examined include unsecured (credit card) debt, mortgage debt, auto debt, and student loans. Disaggregating debt is important because a household's motives for holding debt vary by the type of debt and stage of life.

Figure 5 shows average individual life-cycle holdings of the major types of household debt by age cohort for the years 1999, 2005, 2008, 2010, and 2013.. Although all debt types have a hump-shaped (or inverted u-shaped) pattern, their distributions differ over the ages of the cohorts and by how they move over time. Average unsecured (credit card) debt (Panel A) in 1999 peaked at around age 53, and its pattern seems to replicate the earnings profile in Figure 3. Average credit card debt then increased in 2005 and again in 2008 primarily for cohorts older than age 30. The Great Recession, which started in December 2007, substantially impacted the holding of credit card debt. Between 2008 and 2010, the hump-shaped curves shift downward for all age cohorts. However, the largest deleveraging of credit card debt occurs between 2010 and 2013. In 2008, the average credit card debt at age 50 was over $\$ 7,000$ and by 2013 was down to approximately $\$ 5,000$.

The magnitude of credit card debt is small compared with mortgage debt (Panel B of Figure 5). In fact, average mortgage debt exhibited the most significant change over the period. $\underline{9}$ Average mortgage debt in 1999 peaked at \$58,000 (in 2013 dollars) for cohorts between ages 40 and 50. The increase in both housing prices and home ownership between 1999 and 2008 increased reliance on mortgage financing, shifting average mortgage debt upward in both 2005 and 2008 over all age cohorts.

The increase in mortgage debt not only shifted upward, but the peak also shifted in the direction of younger cohorts. Peak average mortgage debt increased from about $\$ 60,000$ around age 45 in 1999 to about $\$ 117,000$ at age 42 in 2008. After the onset of the Great Recession, by 2010, average mortgage debt had decreased somewhat for cohorts under age 50 . Between 2010 and 2013, however, large mortgage debt deleveraging occurred through gradual paydowns, lower housing prices, short sales and foreclosures, and fewer homebuyers entering the market. This deleveraging is evidenced by average mortgage debt for cohorts younger than age 60 decreasing by more than the previous life-cycle patterns would have predicted. However, mortgage debt has not reverted back to 1999 levels.

A third important household debt category is auto debt (Panel C of Figure 5). In 1999, auto debt varied widely for cohorts between 20 and 30, growing sharply over the age span, and for cohorts between ages 30 and 55 but less sharply. After age 55, auto debt continued to decline. Peak auto debt in 1999 did not exceed \$4,000. Between 1999 and 2008, all cohorts increased their holding of auto debt, but the distribution changed by age. In 2008, auto debt had a more pronounced hump for cohorts in their 30s and, more importantly, peaked at approximately 


\section{Garriga, Noeth, Schlagenhauf}

\section{Figure 5}

\section{Changes in Types of Household Debt Since 1999 by Age Cohort}

\section{A. Average Unsecured Debt}

Unsecured Debt (2013 Dollars)

8,000

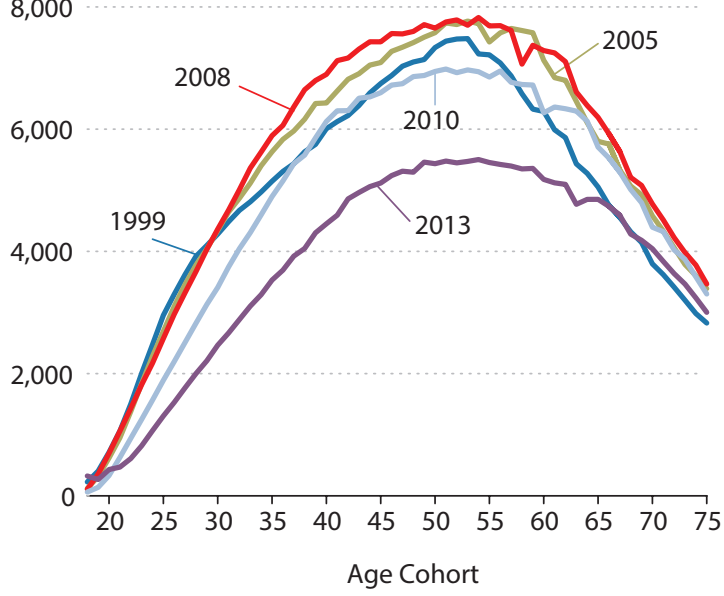

C. Average Auto Debt

Auto Debt (2013 Dollars)

8,000

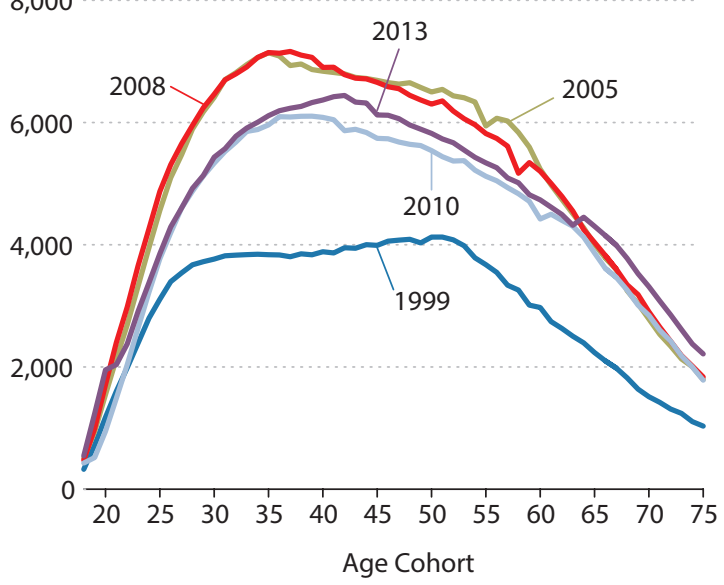

B. Average Mortgage Debt

Mortgage Debt (2013 Dollars)

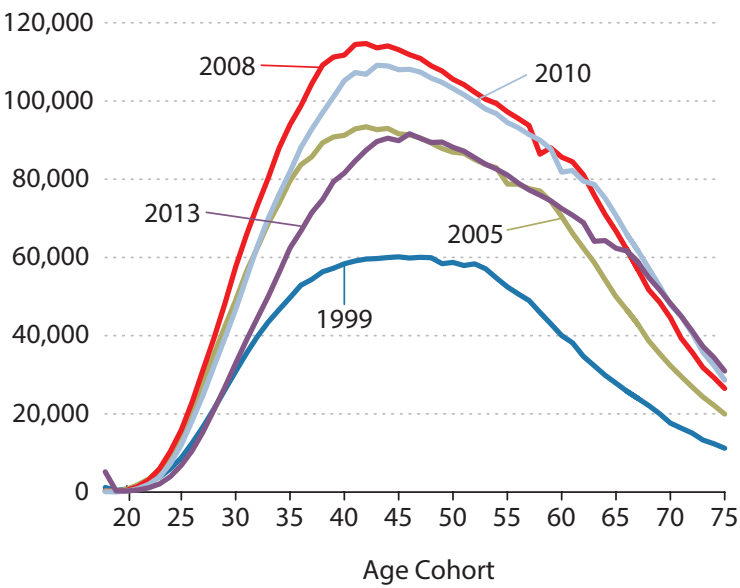

D. Average Student Debt

Student Loans (2013 Dollars)

12,000

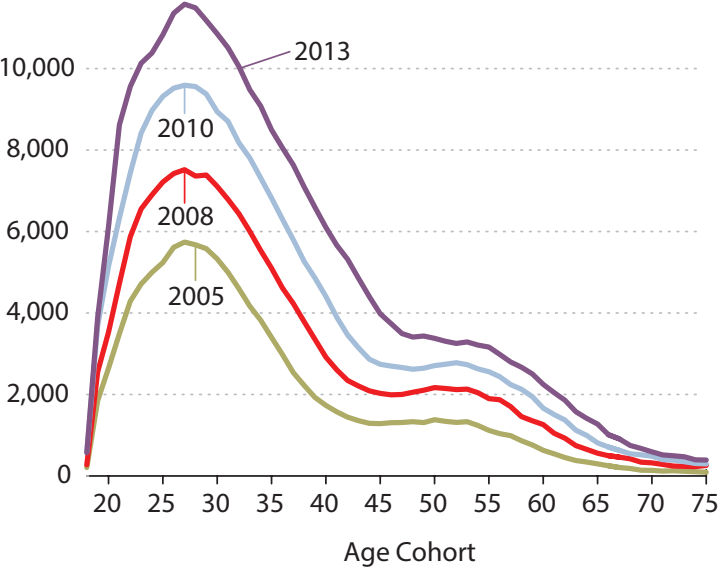

SOURCE: Federal Reserve Bank of New York Consumer Credit Panel/Equifax and authors' calculations.

$\$ 7,000$ - up from around $\$ 4,000$ in 1999. In 2010, auto debt followed the patterns of unsecured and mortgage debt and declined across all ages, but it rebounded in 2013.

The behavior of student loans differs from the other types of debt (Panel D of Figure 5). As with other forms of household debt, student debt increased over the sample period. In contrast to the other types of household debt that deleveraged, student debt continued to grow. By 2013, student debt peaked near \$12,000 and the age profile of student debt changed-it 
Table 2

\section{Conditional Debt-Holding Patterns (percent)}

\begin{tabular}{lrrrrr} 
Debt Holding By Type & 1999 & 2005 & 2008 & 2010 & 2013 \\
\hline None & 36.5 & 35.0 & 32.9 & 33.7 & 34.0 \\
\hline Unsecured Only & 26.3 & 20.0 & 18.5 & 16.9 & 16.7 \\
\hline Mortgage Only & 3.9 & 3.7 & 3.9 & 4.3 & 4.0 \\
\hline Auto Only & 2.9 & 3.2 & 3.5 & 4.0 & 4.0 \\
\hline Student Debt Only & 1.2 & 2.4 & 3.0 & 4.6 & 5.0 \\
\hline Unsecured, Mortgage & 12.7 & 11.4 & 11.4 & 11.0 & 9.9 \\
\hline Unsecured, Auto & 6.3 & 7.0 & 7.2 & 6.1 & 6.5 \\
\hline Unsecured, Student & 1.8 & 2.6 & 2.9 & 3.0 & 3.3 \\
\hline Mortgage, Auto & 0.9 & 1.5 & 1.7 & 1.8 & 1.7 \\
\hline Mortgage, Student & 0.1 & 0.2 & 0.3 & 0.4 & 0.4 \\
\hline Auto, Student & 0.2 & 0.4 & 0.6 & 1.0 & 1.2 \\
\hline Unsecured, Mortgage, Student & 0.6 & 0.9 & 1.2 & 1.3 & 1.3 \\
\hline Unsecured, Auto, Student & 0.7 & 1.4 & 1.8 & 1.8 & 2.2 \\
\hline Mortgage, Auto, Student & 0.0 & 0.2 & 0.2 & 0.3 & 0.3 \\
\hline Unsecured, Mortgage, Auto & 5.5 & 8.9 & 9.3 & 8.1 & 7.6 \\
\hline All Forms & 0.4 & 1.2 & 1.6 & 1.7 & 1.8 \\
\hline
\end{tabular}

SOURCE: Equifax Consumer Panel.

increased across all age cohorts. For those ages 50 and older, the increase is likely a result of parents or grandparents either taking loans or co-signing for their relatives.

The previous figures consider only the dynamics of each form of debt independently. In reality, many individuals hold different types of debt simultaneously. Table 2 uses Equifax data to show the percentages of individuals holding different forms of debt for various years from 1999 to 2013. The largest debt category is "None" (no debt held). In 2013, 34 percent of the sample held no debt. The largest participation rate is for "Unsecured Only" (unsecured credit card) debt, which averaged about 20 percent over the period but has steadily declined since 1999. The next-largest participation rates are for unsecured credit card debt and some other form of debt: the "Unsecured, Mortgage" category (unsecured credit card debt and mortgage debt), which averaged 11.3 percent, followed by "Unsecured, Auto" (unsecured credit card debt and auto debt), which averaged near 6.6 percent. "Unsecured, Mortgage, Auto" is the only category with three forms of debt and a significant average participation rate: 8 percent. The remaining categories have relatively low participation rates, including those that solely or jointly include student debt. The categories with student debt, however, all increased after 1999.

How have the dynamics of debt changed for some of the most representative groups? Figure 6 attempts to address this question by showing different combinations of average debt holdings for different cohorts: mortgage debt (Panel A); mortgage debt and auto debt (Panel B); auto debt and unsecured (credit card) debt (Panel C); and auto debt, unsecured debt, mortgage 


\section{Figure 6}

\section{Selected Conditional Debt Holding Patterns by Age Cohort}

\section{A. Average Mortgage Debt}

Total Value of Debt (2013 Dollars)

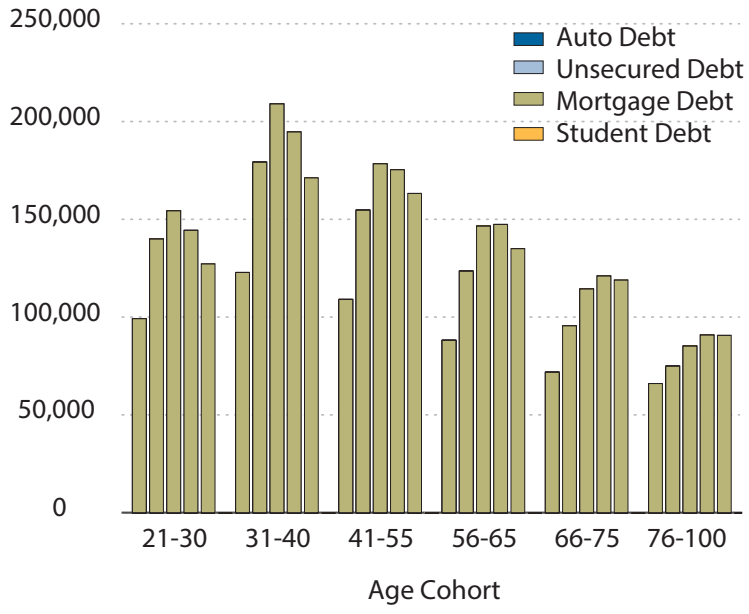

C. Average Auto and Unsecured Debt

Total Value of Debt (2013 Dollars)

30,000

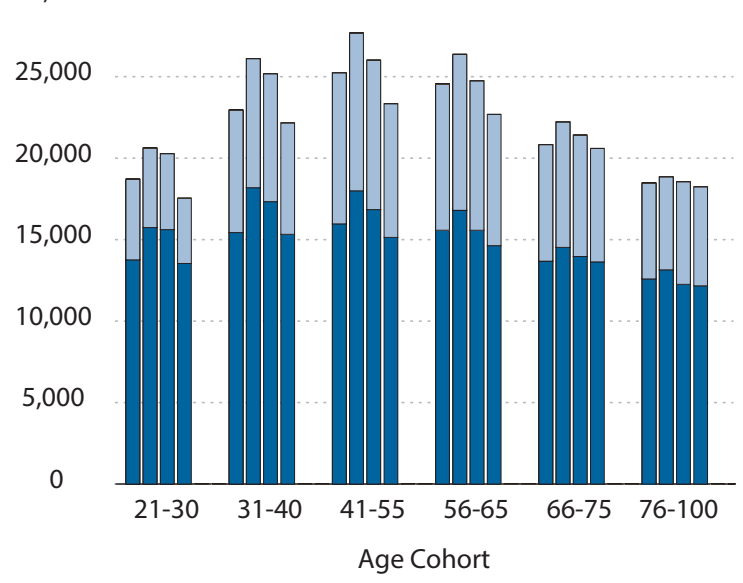

B. Average Mortgage and Auto Debt

Total Value of Debt (2013 Dollars)

250,000

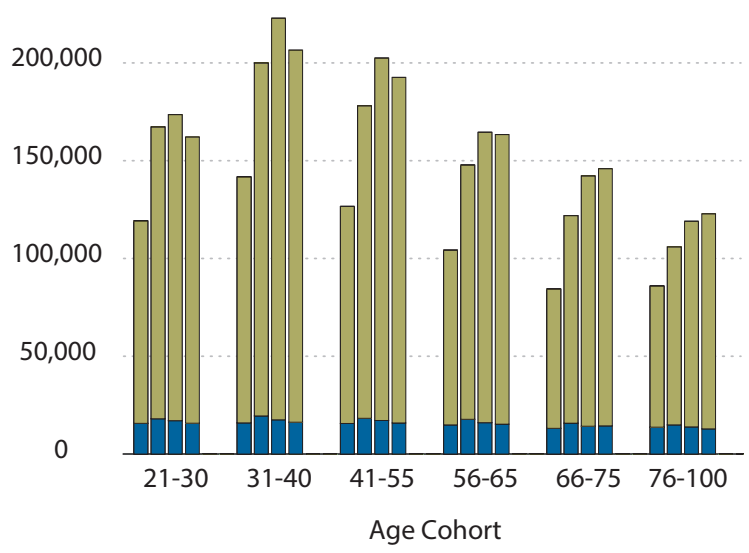

D. Average Auto, Unsecured, Mortgage, and Student Loan Debt

Total Value of Debt (2013 Dollars)

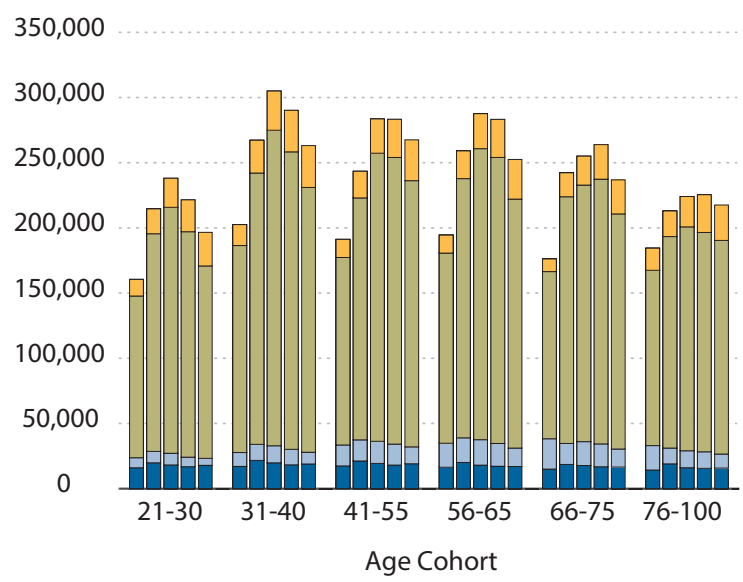

SOURCE: Federal Reserve Bank of New York Consumer Credit Panel/Equifax and authors' calculations.

debt, and student loans (Panel D). Each panel's cohorts hold only the given debt(s) for that panel. For example, Panel A cohorts hold only mortgage debt. The five bars for each cohort correspond to the sample periods 1999, 2005, 2008, 2010, and 2013.

The 1999 sample suggests a humped-shaped pattern for age cohorts. This pattern is more apparent for later years, such as 2005 and 2008. Mortgage debt increased across all cohorts 
over the first three sample years, from 1999 to 2008. After 2008, all age cohorts deleveraged mortgage debt except the 66-75 and 76-100 cohorts.

For individuals who hold both mortgage and auto debt (see Panel B of Figure 6), total debt patterns across age cohorts and periods are more strongly influenced by mortgage debt. Although auto debt follows patterns similar to mortgage debt, the size of mortgage debt obscures these patterns. Because studies find the homeownership rate significantly lower for younger and lower-income individuals (Chambers, Garriga, and Schlagenhauf, 2009), Panel C of Figure 6 shows average unsecured (credit card) debt and auto debt for non-homeowners. The total average debt levels for these individuals are much lower over age cohorts and periods than the first two categories discussed. A clear hump-shaped pattern is evident for 1999. As for individuals with mortgage debt, average total debt in 1999 peaked for the $41-55$ cohort. After 2008, deleveraging of unsecured debt can also be clearly seen. Although average debt declined, the change is quantitatively small compared with individuals who hold mortgage debt.

Panel D of Figure 6 examines debt holding patterns of individuals with all four forms of debt. Even though Table 2 indicates this share of individuals has been increasing over the years, the (average) fraction of individuals in the Equifax sample holding all forms of debt is approximately 1 percent. Each year exhibits a hump-shaped pattern with the peak generally occurring around the 31-40 cohort. The cross-section distribution shifts upward in 2005 and then again in 2008 . In 2008 , total average debt of the $31-40$ cohort was over $\$ 300,000$. After 2008 , the pattern for this cohort remained unchanged, but the distribution shifted downward in each of the following years.

The important lesson from this exercise is that some individuals simultaneously hold different types of debt. To understand the expansion and the contraction of private lending, it is important to consider the four types of lending together. Since the type of lending used to finance a home or automobile is very different from unsecured credit often used to purchase food or clothing, it is critical to analyze the disaggregated behavior of household debt as opposed to total household debt.

\section{MORTGAGE DEBT, DELEVERAGING, AND THE GREAT RECESSION}

The data in the prior sections suggest that during the early 2000s boom-and-bust cycle, real earnings and household debt over all age cohorts positively co-moved, but with personal debt increasing and then decreasing faster than income. These two observations lead to the obvious question of whether debt patterns played an important role in making the 2007-09 recession "Great."

Perri and Steinberg (2012) compare the 1980-82 recession $\frac{10}{10}$ with the Great Recession, two of the most severe post-war recessions, with unemployment around 10 percent. Unemployment during the 1980-82 recession peaked in 1982, while during the Great Recession it peaked in 2009. Table 3 examines the changes in income over the three years before and after each recession. As shown, the pre-recession losses in median income were very similar over the two recessions as were losses in the 20th and 95th percentiles of the income distribution, with the lower (poorer) end hit especially hard. 
Table 3

A Comparison of the 1980-82 (Volcker) Recession with the Great Recession

\begin{tabular}{|c|c|c|c|c|c|}
\hline \multicolumn{6}{|c|}{ 1980-1982 Recession } \\
\hline Income group & $1979(\$)$ & $1982(\$)$ & $1985(\$)$ & $1979-82(\%)$ & $1982-85(\%)$ \\
\hline 95th Percentile & 191.8 & 189.6 & 209.5 & -1 & 11 \\
\hline Median & 71.9 & 65.0 & 71.1 & -10 & 9 \\
\hline 20th Percentile & 33.1 & 26.3 & 29.1 & -20 & 11 \\
\hline \multicolumn{6}{|c|}{ 2007-2009 Recession } \\
\hline Income group & $2006(\$)$ & $2009(\$)$ & 2012 (\$) & 2006-09 (\%) & 2009-12 (\%) \\
\hline 95th Percentile & 289.7 & 277.8 & 270.2 & -4 & -3 \\
\hline Median & 83.2 & 76.0 & 74.5 & -9 & -2 \\
\hline 20th Percentile & 33.6 & 26.9 & 25.0 & -20 & -7 \\
\hline
\end{tabular}

NOTE: All values are in thousands of 2012 dollars.

SOURCE: Perri and Steinberg (2012).

What differentiates these two episodes? One key difference seems to be the recovery of income three years after the recessions. After the 1980-82 recession, median income recovered to pre-recession levels at different speeds. Individuals in the 95th income percentile recovered much more quickly than individuals in the 20th income percentile, who didn't recover to the pre-recession level. Three years after the Great Recession, those in the 20th and 95th percentiles saw no income recovery. Did this slow recovery force individuals to deleverage? Could this be an important factor in the sluggish recovery after the Great Recession?

The prior section documented the increase during the first decade of the 2000s in the number of individuals holding both mortgage and unsecured (credit card) debt and the value of that debt. Innovations in housing finance played an important role in the expansion of home ownership, as discussed in Chambers, Garriga, and Schlagenhauf (2009). In addition, Kiyotaki, Michaelides, and Nikolov (2011), and Garriga, Manuelli, and Peralta-Alva (2012) argue that the increase in the availability of mortgage debt was a key driver of increases in housing prices.

The collapse of house values-used as collateral for borrowing - combined with the slow recovery in household income likely help explain the sluggish recovery. Table 4 shows the change in housing prices in windows around two large recessions (1980-82 and 2007-09). During both recessions, housing prices declined over 10 percent (13.30 percent and 33.30 percent, respectively). However, the level of mortgage defaults (delinquent and foreclosed loans) differed significantly, with nearly zero change in the 1980s versus an increase of 3.53 percent in the 2008-09 period). This difference suggests that a combination of the size of the decline in house values and leverage may have played an important role in the Great Recession. Garriga and Schlagenhauf (2009) studied this question. They reported that, prior to the Great Recession, new mortgage products were introduced to increase households' opportunities for entering the housing market. In contrast to the traditional, fixed-rate mortgage contract that required a 20 percent down payment, these new contracts allowed for a lower down pay- 


\section{Table 4}

\section{House Price Appreciation and Foreclosure Rates (percent)}

\begin{tabular}{lrr} 
Variable & $\mathbf{1 9 8 0 - 8 5}$ & $\mathbf{2 0 0 6 - 0 9}$ \\
\hline De-trended House Price Index (Corelogic) & -13.30 & -33.30 \\
\hline Change in mortgage foreclosures started & 0.33 & 3.53 \\
\hline SOURCE: Corelogic and Mortgage Bankers Association. & & \\
\hline
\end{tabular}

ment and even variable interest rates over the mortgage contract period. In other words, the introduction of new mortgage products changed the leverage position of many homeowners. The greater a homeowner's leverage-mortgage debt-the more a decrease in housing prices will affect home equity.

To measure homeowner exposure to changes in house values, we use data from the Financial Accounts of the United States and the Survey of Consumer Finances to create a home equity multiplier and show how the size of the multiplier depends on total mortgage debt in the economy. The advantage of this approach is that does not require a structural model to analyze the connection between mortgage debt and housing prices. The data suggest that the value of the U.S. residential real estate market in 2007 was about $\$ 20$ trillion. Roughly 25 percent of all houses were owned free and clear, with a total approximate value of $\$ 5$ trillion. The remaining housing stock had $\$ 15$ trillion of mortgage debt. The aggregate ratio of mortgage debt to house values-the loan-to-value (LTV) ratio-was 67 percent.

Since most properties are mortgaged, a decline in housing prices will have a larger impact on homeowner equity the greater homeowner leverage. The home equity multiplier can be formalized as follows. Let $V_{0}$ represent the property value at $t=0$, with property value further decomposed into outstanding mortgage debt, $D_{0}$, and the equity in the house, $E_{0}$. A percent change in the home value can be written as

$$
e=\frac{1}{1-L T V} v
$$

where $v=\left(V-V_{0}\right) / V$ represents a percent change in home value, $e=\left(E-E_{0}\right) E_{0}$ represents a percent change in equity value, and $L T V=D_{0} / V_{0}$. The home equity multiplier implies that a percent change in equity value is amplified by the amount leveraged. When the $L T V=0$. the percentage change in home value and equity are equal, but otherwise the effects are larger.

The next example illustrates the connection between household leverage and housing prices. In Table 5, we examine the effect of a 10 percent house price decline on mortgage contracts with different LTV ratios for the purchase of a $\$ 400,000$ house. If a household pays cash for the house and housing prices drop 10 percent, the loss in equity is 10 percent. If the household borrows $\$ 100,000$ (and pays $\$ 300,000$ cash), that 10 percent drop results in a 13.3 percent loss in equity. If the household borrows $\$ 300,000$ (and pays $\$ 100,000$ cash) and prices drop 10 percent, the loss in equity soars to 40 percent. 


\section{Table 5}

The Effect of a 10 Percent House Price Decline

\begin{tabular}{lccc} 
Mortgage Debt & LTV $(\%)$ & 1 & $\% \Delta \mathrm{E}$ \\
\hline$\$ 0$ & 0 & $1 . \mathbf{L T V}$ & -10.0 \\
\hline$\$ 100,000$ & 25 & 1.33 & -13.3 \\
\hline$\$ 200,000$ & 50 & 2.00 & -20.0 \\
\hline$\$ 300,000$ & 75 & 4.00 & -40.0 \\
\hline
\end{tabular}

SOURCE: Authors' calculations.

This example considers only the effect on a particular homeowner. How does the loss of equity feedback to the economy? With mortgage debt of $\$ 15$ trillion, a 10 percent decline in housing prices would reduce the value of mortgaged houses to $\$ 13.5$ trillion. However, the total mortgage debt would remain unchanged at $\$ 15$ trillion-even though homeowner equity is reduced by $\$ 3.5$ trillion. In other words, homeowner equity has declined by 30 percent. If household income remains unchanged and households have liquid assets to meet mortgage obligations, the effect on the economy may be minimal. If households do not have access to liquid assets, or the amount of liquid reserves decrease, then households may have to adjust expenditures. If the decline in expenditures is a sufficiently large, demand can decline and labor markets can be adversely impacted. The decrease in demand can exacerbate problems in the housing market, causing the economy to decline even more. Historically, this process is very similar to the debt-deflation cycle of Irving Fisher. $\underline{11}$

The equity multiplier can be related to alternative ways to deleverage. A household can pay off the debt or default. Figure 7 examines the value of the equity multiplier and the aggregate foreclosure rates in the United States for the period 1970 to 2007, which includes multiple recessions leading up to the Great Recession. It is clear that fluctuations in housing prices in previous recessions were absorbed by homeowner equity. The expansion of mortgage debt during the housing boom, however, reduced homeowner equity, and the equity multiplier more than doubled.

Table 6 presents micro data from the Federal Reserve Bank of New York Consumer Credit Panel to examine debt holdings of individuals in the 31-40 cohort: (i) only credit card debt or (ii) both credit card and mortgage debt. This cohort was likely to be hard hit by the housing boom and resulting Great Recession and had large variations in debt holdings. In 2008, the average debt holding of these individuals with only credit card debt was $\$ 5,166$. However, the average credit card debt for those in the highest 10 percent of the distribution (those with the largest average debt) was $\$ 27,849$, while that for those in the lowest 10 percent of the distribution (those with the smallest average debt) was $\$ 106$. The large variation within the cohort is even more pronounced for individuals holding both credit and mortgage debt, with individuals in the highest 10 percent holding averages of $\$ 15,516$ and $\$ 773,184$, respectively, and those in the lowest 10 percent holding averages of $\$ 4,256$ and $\$ 36,836$, respectively. A com- 
Figure 7

Home Equity Multiplier and Defaults (1970-2010)

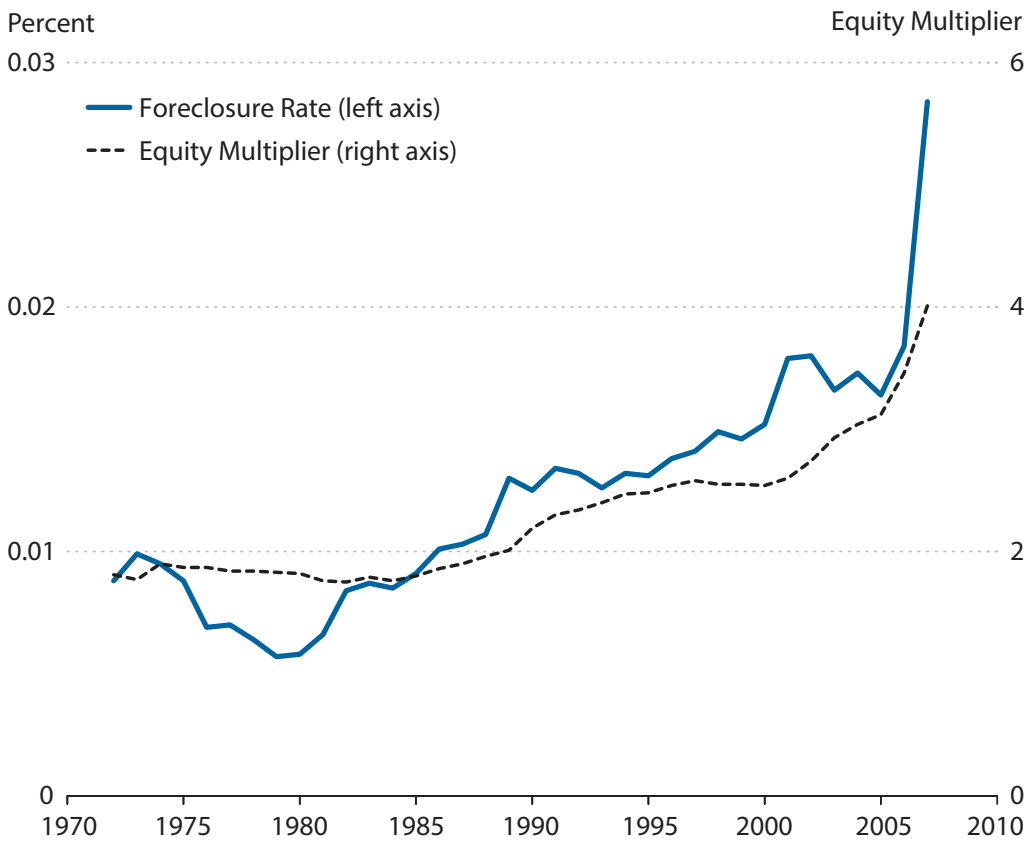

SOURCE: Federal Reserve Bank of New York Consumer Credit Panel/Equifax and authors' calculations.

parison of 1999, 2008, and 2013 indicates a large increase in debt for individuals with both mortgage and credit card debt. By 2013, deleveraging can be clearly seen for individuals holding both types of debt and individuals holding only credit card debt.

An important question is how did these individuals deleverage? One possibility was that they paid down debt, while another was that they defaulted. For individuals holding credit card debt only, the bankruptcy rate actually declined between 1999 and 2013. For individuals holding both credit card and mortgage debt, the bankruptcy rate declined between 2008 and 2013. However, the foreclosure rate between 1999 and 2008 did increase. The foreclosure rate in 2013 exceeded the rate in 1999. Why do we observe a lower level of bankruptcies but a higher level of foreclosures? There are several reasons. One is the relatively small amount of credit card debt compared with mortgage debt. Between 1999 and 2008, average credit card debt declined 12 percent for individuals with only unsecured balances $(\$ 5,863$ vs. $\$ 5,166)$, whereas it increased 12 percent for households that also held a mortgage ( $\$ 7,620$ vs. $\$ 8,756$ ). For these individuals, the increase in credit card debt is small compared with the 67 percent increase in mortgage balances ( $\$ 146,191$ vs. $\$ 243,851$ ). Another important driver could be U.S. bankruptcy law reform in 2005. Li and White (2009) argue that the 2005 reform set the stage for an increase in mortgage defaults by making bankruptcy less available. Their estimates suggest that the reform caused about 800,000 additional mortgage defaults and 250,000 addi- 


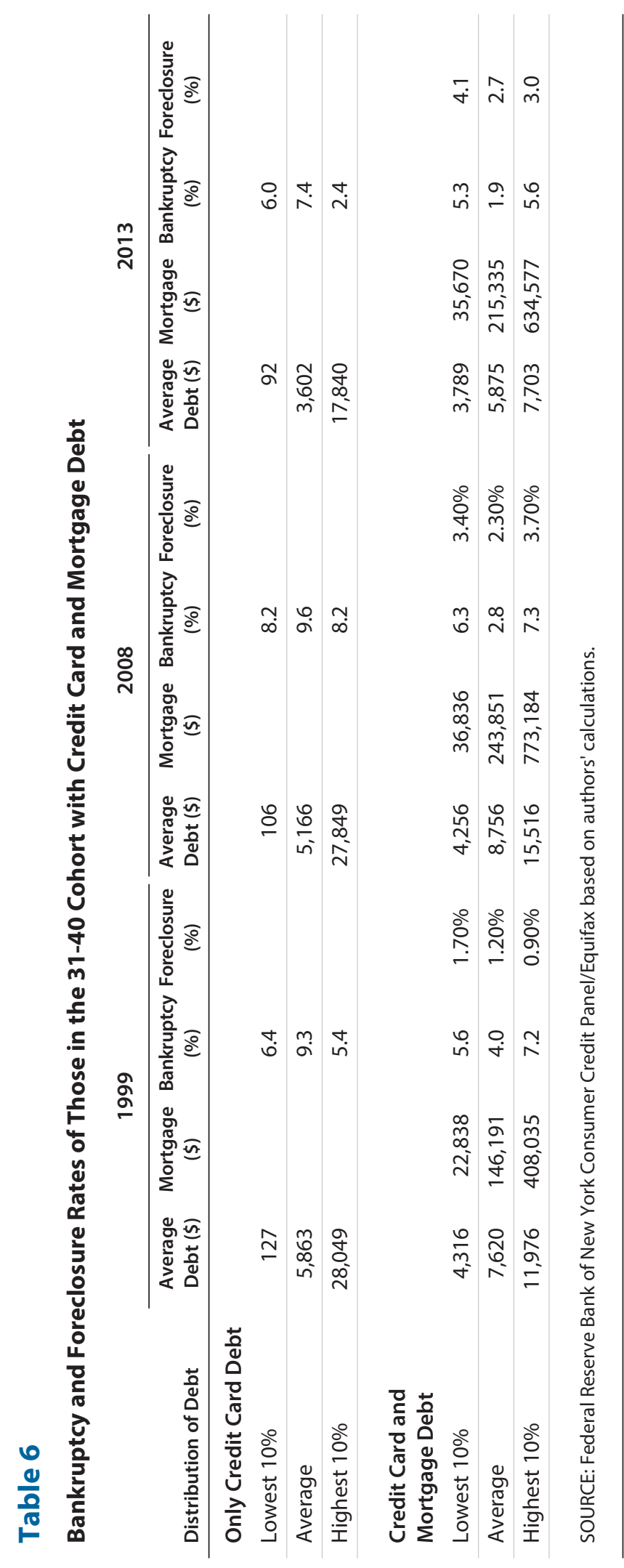


tional foreclosures in each of the following years. This evidence is consistent with the data in Table 6.

Gerardi et al. (2015) discuss the impact of income shocks at the individual level. $\underline{12}$ They find that unemployment as well as negative financial shocks are key predictors of mortgage default. In addition, they use wealth data to identify a limited scope for strategic default, as only one-third of defaulted "underwater" loans (mortgages with negative equity) are held by borrowers with sufficient assets to pay their mortgage.

\section{CONCLUSION}

U.S. households take on different kinds of debt at different points in their lives, including student loans, mortgages, credit card debt, and auto loans. This paper examines the role debt played in the Great Recession, exploring which forms of debt contributed to the large increases in aggregate debt during the recent economic expansion (boom) and collapse (bust). A very simple macroeconomics framework-the life-cycle model-is used to discuss household debt. Our analysis suggests that several important changes in debt composition have occurred. Along the intensive margin-average debt per borrower-borrowers have been altering the amount of debt held. For example, prior to the Great Recession, there were large run-ups in the average debt per borrower for both student debt and mortgage debt. While the amount borrowed to finance college has continued to grow, the average mortgage debt has decreased in the wake of the downturn. Along the extensive margin - the number of borrowers-there are many patterns in the types of debt individuals hold. For example, many more individuals hold student debt than in prior years.

This exercise offers some important lessons. One is that considering the disaggregated behavior of debt, as opposed to a consolidated balance, is critical to understanding the deleveraging episode. For individuals with no mortgage debt (or with sufficient home equity), the reduction in credit balances partially responded to a decline in income, as reported in Section 3. For individuals with mortgages, the amount of home equity combined with income risk is very important for understanding their deleveraging behavior. 


\section{Garriga, Noeth, Schlagenhauf}

\section{NOTES}

1 Personal income is income received from all sources. It includes income received by persons from participation in production, plus government and business transfer payments, plus government interest (which is treated like a transfer receipt).

$\underline{2}$ It should be remembered that in a particular period individuals differ by age. If all individuals' debt decisions were aggregated at a particular date, the result would be a point in Figure 1.

3 An alternative framework for studying consumption behavior is Friedman's (1957) permanent income framework. Because different types of debt often vary by age, the life-cycle model seems more appropriate for our purposes.

4 More formally, economists state that borrowing becomes a problem when the lifetime budget constraint does not hold. This constraint states that the present value of lifetime consumption expenditures must equal the present value of lifetime after-tax income. If total lifetime borrowing does not violate this constraint, then borrowing is acceptable.

$\underline{5}$ The assumption of the hump-shaped pattern captures well the average pattern of earnings. However, there are some individuals that have an increasing pattern of earnings until retirement age.

$\underline{6}$ Because of the different data sources for Figures 3 and 4, different measures and years of data are used. The income measure includes earnings. It is clear that Hispanic mean household income remained below the average earnings of all households.

7 Often researchers examine the 10-50 ratio, which compares households in the 10th percentile with median households. The 30th percentile is used in this paper to avoid the distortions introduced by government transfer programs.

8 The averages for the various debt categories are conditional on individuals holding nonzero debt for the category.

9 The figure reports unconditional average mortgage debt by age adjusted for inflation. By unconditional debt holding, we mean the average over all individuals whether or not they hold mortgages or other forms of debt.

10 Although there were two recessions during the 1980-82 period (as determined by the National Bureau of Economic Research), because of their quick succession, we treat them as one episode.

11 Mian and Sufi (2011) show that areas with the highest decreases in housing prices were also the areas that had the largest job losses. In addition, Herkenhoff (2013) finds that large growth in credit access leads to deeper and longer recessions as well as moderately slower recoveries.

12 From a macroeconomic perspective, Herkenhoff (2013) has stressed that the dynamics of unemployment affect bankruptcy and foreclosure decisions.

\section{REFERENCES}

Chambers, Matthew; Garriga, Carlos and Schlagenhauf, Don E. "Accounting for Changes in the Homeownership Rate." International Economic Review, August 2009, 50(3), pp. 677-726; https://doi.org/10.1111/j.1468-2354.2009.00544.x.

Friedman, Milton. A Theory of the Consumption Function. Princeton: Princeton University Press, 1957.

Garriga, Carlos; Manuelli, Rodolfo and Peralta-Alva, Adrian. "A Model of Price Swings in the Housing Market." Working Paper No. 2012-002A, Federal Reserve Bank of St. Louis, July 2012; https://research.stlouisfed.org/wp/2012/2012-022.pdf.

Garriga, Carlos and Schlagenhauf, Don. "Home Equity, Foreclosures, and Bail-outs." Unpublished manuscript, 2009.

Gerardi, Kristopher; Herkenhoff, Kyle F.; Ohanian, Lee E. and Willen, Paul S. "Can't Pay or Won't Pay? Unemployment, Negative Equity, and Strategic Default." NBER Working Paper No. 21630, National Bureau of Economic Research, 2015.

Herkenhoff, Kyle F. "The Impact of Consumer Credit on Unemployment." Working paper, University of Minnesota, August 2013. 
Kiyotaki, Nobuhiro; Michaelides, Alexander and Nikolov, Kalin. "Winners and Losers in the Housing Markets." Journal of Money, Credit, and Banking, March-April 2011, 43(2-3), pp. 255-96; https://doi.org/10.1111/j.1538-4616.2011.00374.x.

Li, Wenli and White, Michelle J. "Mortgage Default, Foreclosure, and Bankruptcy." Working Paper No. 15472, National Bureau of Economic Research, November 2009.

Mian, Atif T. and Sufi, Amir. "House Prices, Home Equity-Based Borrowing, and the US Household Leverage Crisis." American Economic Review, August 2011, 101(5), pp. 2132-156; https://doi.org/10.1257/aer.101.5.2132.

Perri, Fabrizio and Steinberg, Joe. "Inequality and Redistribution during the Great Recession." Economic Policy Paper 12-1, Federal Reserve Bank of Minneapolis, February 2012; https://minneapolisfed.org/ /media/files/pubs/eppapers/12-1/epp_12-1_inequality.pdf.

\section{BIBLIOGRAPHY}

Atkinson, Anthony B; Piketty, Thomas and Saez, Emmanuel. "Top Incomes in the Long Run of History." Journal of Economic Literature, March 2011, 49(1), pp. 3-71; https://doi.org/10.1257/jel.49.1.3.

Attanasio, Orazio P. "Consumption," in John B. Taylor and Michael Woodford, eds., Handbook of Macroeconomics. Volume 1B. Chap. 11. New York: Elsevier Science, North Holland, 1999, pp. 741-812.

Bernanke, Ben S. "The Macroeconomics of the Great Depression: A Comparative Approach." Journal of Money, Credit, and Banking, February 1995, 27(1), pp. 1-28; https://doi.org/10.2307/2077848.

Browning, Martin and Crossley, Thomas F. "The Life-Cycle Model of Consumption and Saving." Journal of Economic Perspectives, Summer 2001, 15(3), pp. 3-22; https://doi.org/10.1257/jep.15.3.3.

Bureau of Economic Analysis. "Glossary." N.d.; http://www.bea.gov/glossary/glossary.cfm?letter=P.

Chetty, Raj; Hendren, Nathaniel; Kline, Patrick and Saez, Emmanuel. "Where Is the Land of Opportunity? The Geography of Intergenerational Mobility in the United States." Quarterly Journal of Economics, November 2014, 129(4), pp. 1553-623.

Deaton, Angus. Understanding Consumption. Oxford: Oxford University Press, 1992; https://doi.org/10.1093/0198288247.001.0001.

Díaz-Giménez, Javier; Glover, Andy and Ríos-Rull, José-Víctor. "Facts on the Distribution of Earnings, Income, and Wealth in the United States: 2007 Update." Federal Reserve Bank of Minneapolis Quarterly Review, February 2011, 34(1), pp. 2-31; https://www.minneapolisfed.org/research/qr/qr3411.pdf.

Fisher, Irving. "The Debt-Deflation Theory of the Great Depression." Econometrica, 1933, 1(4), pp. 337-57; https://doi.org/10.2307/1907327.

Garriga, Carlos and Schlagenhauf, Don. "Aggregate and Distributional Dynamics of Consumer Credit in the U.S." Unpublished manuscript, Federal Reserve Bank of St. Louis, 2015.

Heathcote, Jonathan; Perri, Fabrizio and Violante, Giovanni L. "Unequal We Stand: An Empirical Analysis of Economic Inequality in the United States, 1967-2006." Review of Economic Dynamics, January 2010, 13(1), pp. 15-51; https://doi.org/10.1016/j.red.2009.10.010.

Modigliani, Franco and Brumberg, Richard. "Utility Analysis and the Consumption Function: An Interpretation of Cross-Section Data," in K. Kurihara, ed., Post-Keynesian Economics. New Brunswick, NJ: Rutgers University Press, 1954, pp. 388-436.

Piketty, Thomas. Capital in the Twenty-First Century. Cambridge, MA: Belkap Press, 2014; https://doi.org/10.4159/9780674369542.

Piketty, Thomas and Saez, Emmanuel. "Inequality in the Long-Run." Science, May 2014, 344(6186), pp. 838-43; https://doi.org/10.1126/science.1251936.

Williamson, Stephen D. Macroeconomics. Fifth Ed. New York: Pearson-Addison Wesley, 2014. 
